\title{
THE BURDEN OF THE EGYPTIAN MUSLIM BROTHERHOOD'S HISTORICAL LEGACY: THE IDEOLOGY AND AGENDA
}

\author{
Mkouboi Mohamed ${ }^{*}$
}

\begin{abstract}
The aim of the study was the Egyptian Muslim Brotherhood's history focusing on its ideology and agenda. In this regard, the 18th century economic development in the Western Europe influenced the Arab and the Muslim Worlds in a way that Muslim scholars attempted to present an alternative system to the attractiveness of the Western modernization. However, the EMB founded in 1928, despite its tirelessly struggle, full of confrontations and flexibility at the same time towards the domestic as well as the international Community actors failed to achieve its first step agenda which is ruling Egypt. EMB's regional and International expansionism ambition might be the reason behind its failure to be accepted by the regional secular parties, Egyptian Copts and the International Community main actors such as U.S. and UK.
\end{abstract}

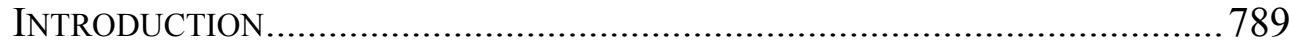

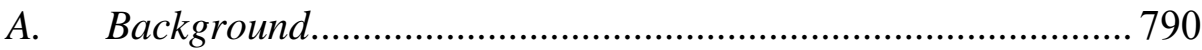

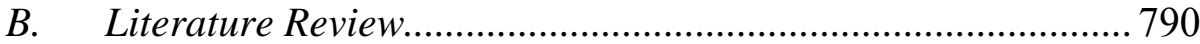

I. EGYPTIAN MuSLIM BROTHERHOOD's IDEOLOGY AND AGENDA ................791

A. Egyptian Muslim Brotherhood's Ideology..................................792

B. Egyptian Muslim Brotherhood's Agenda ....................................796

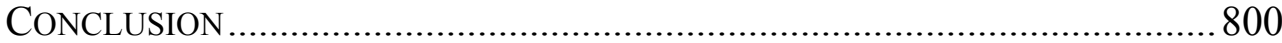

\section{INTRODUCTION}

This paper is a report of examining the Egyptian Muslim Brotherhood's (EMB) history focusing on its ideology and agenda. The study was based primarily upon analysing selective scholarly books, journals and articles highlighting the history of the organization. In addition, the author also examined books, journals and articles written by EMB's founder, writers and active members. This paper presents the background of the study, the focus of the literature review followed by the arguments of the paper and finally the conclusion.

\footnotetext{
${ }^{*}$ PhD student in Political Science, Kyushu University. Research fields: Middle East Politics, the Egyptian Muslim Brotherhood.
} 


\section{A. Background}

The rise and decline of the Egyptian Muslim Brotherhood after the Egyptian Uprising on January $2011^{1}$ raises relative questions among scholars and observers of the Middle East and the North African regions. The victory of EMB's candidate in the presidential elections on June 30, 2012, inspired mainly political scientists to focus on the ideology and agenda of "Political Islam" studies in order to predict the country's future. Nevertheless, the unexpected removal of Muhammad Morsi from power by Marshal Abdel Fattah el-Sision July 3, 2013, followed by the dissolution of the EMB in 2014 generated confusion among researchers of the Middle East studies in particular. The fundamental question among scholars regarding this phenomenon might be: What's wrong with EMB? To answer this question, scholars and observers presented several answers. Some argued that, EMB has no experience in ruling a challenging country like Egypt. Others accused the army of conspiracy against EMB's political and economic agenda in the country. The International community led by the U.S. in its turn, was reluctant to officially condemn the "change regime" by force carried out by the Egyptian military Forces. This controversial position among the domestic and the International political actors is, in fact, the driven force of writing this paper. Accordingly, the author looked at the domestic and the international negligence vis-à-vis EMB's catastrophe. In this regard, the author assumed that, the controversy of EMB's ideology and its short and long term agenda could be one of the main reasons behind the anti-EMB's political ambition inside and outside Egypt. Answering the question: What's wrong with EMB? The author suggested, EMB's ideology and agenda are the main problems among the domestic actors such the military forces and the International Community actors such as the U.S. To justify the answer provided by the author, the study presented a brief episode of the EMB's history focusing on its ideology and agenda.

\section{B. Literature Review}

This paper examined the Egyptian Muslim Brotherhood's ideology and agenda. In the case of its ideology, almost, all scholars of this particular field often situate the origin of EMB's ideology in the late of the 19th century. During this period, few imminent Muslim scholars engaged themselves to convince Muslims to look at the industrial revolution of the

\footnotetext{
${ }^{1}$ The Egyptian people went to the streets on January 25th, 2011, and consequently the Egyptian President, Mubarak resigned on February 11th, 2011.
} 
18th and 19th centuries in Europe and the US as common human efforts, encouraged by Islam more than 1,000 years ago. "The prominent Muslim reformist scholars of the EMB's ideology are Jamal ad-Din al-Afghani (1838-1897), Muhammad Abduh (1849-1905) and Muhammad Rashid Reda (1865-1935)",2. The focus of these scholars was about presenting Islam as a religion that encourages social, cultural and economic developments based on the Islamic principles and values. The arguments of these three Muslim scholars are mainly two: (1) Muslims should not be much proud of the Western culture because Islam itself should be considered as a better reference for them instead of incomplete system; (2) Being independent from foreign economic and cultural dominances is the key for Muslims to be able to compete the Westerners in the political, economic and social domains. "The chief aim of the father of 'Political Islam', Afghani, in all his untiring efforts and ceaseless agitation was the accomplishment of the unification of all Muslim peoples, under one Islamic World, over which the one Supreme Caliph ${ }^{3}$ should bear undisputed rule, as in the glorious days of Islam before its power had been dissipated in endless dissensions and divisions, and the Muslims' lands had lapsed into ignorance"4. This vision is problematic on the eyes of secularist political actors and the ruling monarchy in the Middle East and the North African regions. Furthermore, the international main actors directly or indirectly reject the ideology of the Brotherhood.

However, in order to narrow down the study, the author of this study primarily argued that, EMB's ideology and agenda might be the main problem.

\section{EGYPTIAN MUSLIM BROTHERHOOD’S IDEOLOGY AND AGENDA}

In this section, the author highlighted two different parts: First, the Egyptian Muslim Brotherhood's ideology based on Western scholarly works followed by the Egyptian Muslim Brotherhood's ideologists' own interpretations and explanations through their books, magazines and articles. The second part covered the Muslim Brotherhood's Agenda or the answer of the following question: What does the Egyptian Muslim Brotherhood exactly want to achieve in their long historical struggle to power?

\footnotetext{
${ }^{2}$ Ramadan TariQ, L'Islam et le Reveilarabe 159 (Lyon: Presses du Chatelet 2011).

${ }^{3}$ In Slam, "Caliph" means leader, president, Imam or whatever given name characterising the supreme leader of all Muslims. This is to say, the term Caliphate is not necessary but the role played by the leader.

${ }^{4}$ AdAms C. Charles, Islam AND Modernism In Egypt 13 (London: Oxford University Press 2000).
} 


\section{A. Egyptian Muslim Brotherhood's Ideology}

The ideology of the Muslim Brotherhood might be presumed by the combination of "religion and state" altogether. This altogether pattern seems to be misunderstood or rejected by many political actors, scholars and ordinary citizens, especially in the Western world in the 21 st century. The misunderstanding, rejection or altogether of the combination of "religion with the state" resulted from the economic success of the 18th and the 19th centuries of the Western Europe. Scholars mainly from this elitist majoritarian bloc disagree with the concept of the dual pattern: "religion and state" as a solution of the challenges the world is facing today. Consequently, the Egyptian Muslim Brotherhood's ideology which claims that "Islam is the solution" cannot be wildly accepted even by the ruling secular governments and secular parties within the Middle East and the North African regions. However, since the late 19th century, the ideology of the contemporary Islamist movements in general and the Muslim Brotherhood in particular became worldwide but in the negative sense especially in the Western World. As far as the ideology of the Brotherhood is concerned, Ziad Munson mentioned, "The basic worldview of the Muslim Brotherhood was rooted in the Hanbali School of Islamic thought. It is one of four major traditions for understanding and interpreting Islamic law, and the most conservative in terms of its insistence on a literal reading of the Quran and other texts ${ }^{5}{ }^{6}$. However, through experiences and many challenges, the Brotherhood's interpretations of the Islamic texts extended beyond the Hanbali School of thought and covered all other Islamic schools as long as they provided a flexible interpretation of Islam of the 20th and 21 st centuries. However, this flexible interpretation of the Islamic texts often accused as just political tactics for EMB, claiming that, the organization has hidden an extremist agenda.

Overall, the flexible Islamic interpretation adopted by the Brotherhood attracts many Muslims in the Middle East and beyond to be sympathetic toward the organization due to the belief that EMB's Islamism is the most suitable to the geo-socio-political situations of the 21 st century. In the light of the term "Islamism", the letter is often used instead of "Political Islam"

\footnotetext{
${ }^{5}$ The main sources of Islam are "Qur'an" and the acts and says of the Prophet Muhammad. The acts and the says of Muhammad are known as "Sunnah". However, through centuries many books have been written explaining and interpreting matters related to different periods and different circumstances. Accordingly, there is another source called "Ijmaa". The letter source is the consensus on unclear issues among the existing imminent scholars in a given place and period.

${ }^{6}$ Munson Ziad, Islamic Mobilization: SOCial Movement Theory AND the Egyptian Muslim BROTHERHOOD 489 (U.S.A: University of California Press 2001).
} 
by many scholars of Middle East studies, due to its shorten and comparable pattern to similar scientific terminologies such as "Capitalism", "Communism", Socialism" and so forth. More and more often the term "Islamism" is associated to all Islamist movement ideologies including the violent organizations such as "al-Qaida and the Islamic State of Iraq and the Levant (Syria) (ISIS); and the none violent organizations such as the Egyptian Muslim Brotherhood, the Tunisian "Nahdha" and the (Turkish: Adaletve Kalkınma Partisi: Justice and Development Party ) (AKP). Far from these conflicting views of scholars of the Middle East studies, the study served the term "Political Islam" as EMB's ideology based on its socio-religio-political activities after declining its power struggle from any kind of violent tactics in the 1970s. This new pacifist strategy brought a huge mobilization and recruitment to the Brotherhood as it has been stated by Ziad Munson, political scientists and Middle East scholars have been keenly aware of the more general growth of Islamic groups in Egypt and elsewhere in the region since at least the early 1970s"7.

"Political Islam as the EMB's ideology" is defined and interpreted differently by mainly Western scholars and EMB's ideologists, writers and activists. Consequently, the author covered arguable approaches so that the readers can understand the different interpretations and definitions often found in many scholarly books, journals and articles. First, based on the mainstream interpretation of "Political Islam", the majority of Western scholars describe it based on the Western historical, ideological, political and sociological backgrounds. These backgrounds are shortly described as "Western social theory ${ }^{8}$ ". In their turn, the Muslim Brotherhood's ideologists and writers define and interpret "political Islam" based on their Islamic ideological interpretation and conviction. The author of this particular paper argued that, the reason behind the divergent definitions and explanations of "Political Islam" are the social, cultural and academic backgrounds of two different civilizations: Islamic Civilization vs. Western Civilization. In fact, as the Western Civilization practically proved its advancement, "During the period of industrialism, machines began to be used to do work and industry grew rapidly" 9 , Islamic Civilization ideologists became weak and incapable to convince Western scholars the practicability and effectiveness of the combination of "religion to state".

\footnotetext{
${ }^{7}$ Munson Ziad, Islamic Mobilization: Social Movement Theory and the Egyptian Muslim BROTHERHOOD 490 (U.S.A: University of California Press 2001).

${ }^{8}$ Western political theory basically explains "the relationship between nationalism, political identity and citizenship participation" (Tunner 2000, 1).

${ }^{9} 792$ (Oxford University Press 1948).
} 
The poor performance in the political, social and economic domains in the majoritarian Muslim countries mainly from the late of the 19th century do not convince the Middle East secular parties, monarchies and the Western World to allow EMB to rule Egypt.

The following definitions and interpretations of "Political Islam" are shared by many Western scholars as well as Middle East secularists: According to Charles Hirschkind, the shortest definition of Political Islam is "Islam used to a political end"10. The same scholar added that, a general problem with the term "Political Islam" is that, "Yet a problem remains, even in such seemingly obvious examples: In what way does the distinction between the political and none political domains of social life hold today? Many scholars argued that, "Political Islam" involves an illegitimate extension of the Islamic tradition outside of the properly religious domain it has historically occupied" "In his argument, Hirschkind suggested that, "the term 'political Islam' has been adopted by many scholars in order to identify this seemingly unprecedented irruption of Islamic religion into the secular domain of politics and thus to distinguish these practices from the forms of personal piety, belief and ritual conventionally subsumed in Western scholarship under the unmarked category Islam" ${ }^{\prime 2}$. Based on this argument, Rajeev Bhargava mentioned, "In Western Europe where religion is a personal response to divinity, still largely private, change has come from migrant workers of former colonies and intensified globalization" 13 . Religion as a personal choice with no interference in the state affairs became the most accepted interpretation in the Western World. Furthermore, secular countries give freedom to practice religion as a human right pattern. Rajeev Bhargava cited from three scholars that "Several Western scholars claim that by enjoining believers to leave behind religious convictions when they step into public life, secularism shows hostility to believers, inhibits diversity, and homogenizes the public domain. Others say, it is suited to Protestantism and religious that are weakly protestantized, but excludes or is inimical to other religions. Secularism is said to be a parochial doctrine with universalistic pretensions (Kean 2000, 14-18; Connolly 1999, 23-5; Asad

\footnotetext{
${ }^{10}$ Knudsen Are, Political Islam in the Middle East: Chr. Michelsen Institute Development Studies AND Human Rights (Norway: Chr. Michlsen Institute 2003). Available at http://bora.cmi.no/dspace/bitstream/10202/166/1/R2003-03.pdf (last visited December 2, 2014).

${ }^{11}$ Hirschkind Charles, What is Political Islam? MidDLE EAST RePORT 12 (Washington, DC: MER205 1997). Available at http://www.merip.org/mer/mer205/what-political-islam (last visited May 10, 2012).

${ }^{12} I d$.

${ }^{13}$ Bahargava Rajeev, The Oxford Handbook of Political Theory 637 (New York: Oxford University Press, Inc. 2006)
} 
2003)" $" 14$.

In the light of the above Western interpretations of religion's implication on the state affairs, the Muslim Brotherhood's ideologists, writers and activists rejected the idea of separating Islamic religion from the state affairs. Accordingly, the founder of EMB Hassan al-Banna mentioned, "The one who thinks that Islam does not include politics or politics is not one of the constituents of Islam, he or she committed injustice against himself and against his knowledge vis-à-vis Islam" ${ }^{\prime 1}$. Furthermore, Yusuf al-Qaradawi, the most respected scholar among Muslim Brotherhood's adherents, mentioned, "For the West, Christianity means the Church, the Pope, the tyranny of the priesthood and the spirit. Where is this in Islam?"16. Qaradawi's question refers to the origin of separating "Christianity from state" in Western Europe before and after the French revolution in the 18th century. However, it seems that, Western scholars in the 21 st century do not necessarily argue based on the historical aspect, but they backed their arguments based on the relationship between secularism and modernism.

In the case of Egypt, Mitchell reported that, "familiar process of secularization accompanies urbanization in Egypt as elsewhere" 17 . For the Brotherhood's ideologists, there is a sort of agreement that even before the 8th century, there was a decline of the academic development within the Muslim scholars that caused the decline of the economic, political and social domains in the Muslim World: One of the well-known scholars among Muslims, Ibn al-Qayyim mentioned that, "Because of the deadlock of the Muslim scientists, statesmen in the Muslim World innovated their own political constitution far away from the Islamic sharia"18.

Similarly, one of the ideologists of "Political Islam", Muhammad Rashid Reda (1865-1935) emphasized more on the importance of critically reading and understanding the Islamic texts. In a magazine called Al Manar, Reda stated, "While these laws should be based upon the Al-Qur'an and the Sunnah, they should be subject to change from age to age, according to the requirements of each age". He continued his argument proclaiming that, "The rigid and unchangeable character of the enactments of the four rites is one of the principal reasons for the backwardness of Muslim nations today; and because of this, the Divine Law of Islam has been rejected by many

\footnotetext{
${ }^{14}$ Id. at $637-8$.

15 "Rasa'il al-Banna, 199 (1906-1949)" is a collection of EMB's founder's articles, seminars, essays and so forth. This collection is one of the EMB' sources in terms of its ideology and agenda.

${ }^{16}$ QARADAWI YusuF, From FiQH AL-DAUlat In IsLAm 13 (Egypt: Dar al-Shuruk 2001).

${ }^{17}$ Richard P. Mitchell, The Society of THE Muslim Brothers 10016-4314 (New York: Oxford University Press, Inc. 1969).

${ }^{18}$ QARADAWI Yusuf, From FiQH AL-DAUlat IN Islam 7 (Egypt: Dar al-Shuruk 2001).
} 
Muslim governments as unsuitable for present conditions" ${ }^{\text {,19. }}$.

Whatever these two different arguments (Western and Brotherhood's interpretations) are, in the light of the recruiting strategies and mechanisms of the Egyptian Muslim Brotherhood, the EMB's flexible ideology towards the modernization and its continuous review based on its experiences plays a great role to recruit a huge number of the Egyptian citizens and the youth in particular to the organization. Furthermore, this flexible approach often unites Western statesmen and EMB's leadership for discussions. Recently, on January 30, 2015, five members of EMB held a controversial meeting organized by "the Center for the Study of Islam" in Georgetown University. In this controversial meeting, U.S. officials attended, but few days later, American's administration said, it was just a meeting organized by the University only ${ }^{20}$. However, EMB's flexibility and willing to normalize its relationship with the international community often treated as political tactics as it has been mentioned in page 3. This doubtful atmosphere is inspired by debatable subjects such as 'Copts' position under EMB's agenda, the implication and the interpretation of Sharia in the state affairs, MB's vision towards democracy; the Egyptian banking system is based on the notion of interests for lending and savings. Will the Brotherhood keep it or not. In addition, the approach towards the existing Peace Treaty between the Egyptian and the Israeli authorities made in 1979 is another sensitive issue mainly between EMB and the US. Furthermore, MB itself was and is currently considered as a terrorist organization since $1954^{21}$, due to its traditional violent legacy against the states and its connection with Hamas. The regional authorities' suppression against the Brotherhood for many decades was also followed by intensive media coverage against the Organization inside and outside Egypt. Under these doubtful features and EMB's flexible approaches, still scholars as well as observers may be interested in knowing the final goals or in more elaborated term the agenda of the organization.

\section{B. Egyptian Muslim Brotherhood's Agenda}

The Egyptian Muslim Brotherhood' struggle for power aims to achieve certain objectives. These objectives are divided into two based on this particular study: short time goals and long term goals: (1) The short term

\footnotetext{
${ }^{19}$ ADAMS C. Charles, IsLAM AND Modernism In EgYpt 193 (London: Oxford University Press 2000).

${ }^{20}$ Al-Minshawi MuHAmmed, Al-Shuruk NewSPAPER (Egypt: Bawabat al-Shuruk 2015). Available at http://linkis.com/www.shorouknews.com/T5JSi.

${ }^{21}$ EMB was dissolved in 1948, 1954 and finally in 2014 by the Egyptian respective authorities.
} 
goals are concentrating on the Egyptian society and the country as a state. To win the hearts of the Egyptian citizens, the organization intends to send a message to the people that "an Islamic state and held that, true Islam was essentially democratic and capable of solving the problems of the modern world" 22 . Therefore, the author argued that, the primarily agenda for the Brotherhood is to mobilize and recruit as many Egyptians as they can for attaining power. The recruiting process is the very actual and essential role played by the Brotherhood's activists since 1930s until today.

Like other political parties in Egypt, the only existing strategy to boost the Organization to power is through populous campaigns. In Egypt, the second option to get into power is through military interference. Nevertheless, the letter option seems to be impassable, as filtrating machinery has been implemented in order to be sure that, the military monopoly is all under none Islamist influences ${ }^{23}$. Here we come to know the reason behind the social services and economic activities tirelessly engaged by the organization to reach as many Egyptians as possible. This recruiting ambition inspired "the Muslim Brotherhood to cut across estranged social structures such as the modern working class, the urban poor, the young, and the new middle class, which form a support base" ${ }^{24}$. Within the short term agenda's perspective, the Brotherhood aims to ensure good governance once the organization rules the country. However, the less than one year ruling experience from 2012 to 2013, places the organization in a critical position, as it has been hugely blamed and qualified as incapable to rule the country. This blame became the most powerful critics against the organization for instance because good governance was, in fact, its potential argument and goal against the successive governments since its inception in 1928 until today.

In the case of the long term agenda (2), the organization has first a regional dominant goal. Like Jamal Abdel Nasser's "pan-Arabism", the Brotherhood aims to first establish a "pan-Islamism" in the region as the center of the international Muslim World. This regional ambition is wellunderstood by the current regional leaders. Consequently, the leadership in the region often confronts the organization. The most severe attacks against the Brotherhood in general were Saudi's interior minister, Amir Naiflbn Abdel Aziz in 2004. Naif stated that, the Muslim Brotherhood is the

\footnotetext{
${ }^{22}$ Munson Ziad, Islamic Mobilization: Social Movement Theory and the Egyptian Muslim BROTHERHOOD 490 (U.S.A: University of California Press 2001).

${ }^{23}$ The military recruitment is very restricted to citizens with no Islamist mind-sets. As it is a high class job, the children from military high rank officers often have the opportunities to be recruited. ${ }^{24}$ Munson Ziad, Islamic Mobilization: Social Movement Theory and the Egyptian Muslim BROTHERHOOD 2 (U.S.A: University of California Press 2001).
} 
mainspring of all violent activities in the Middle East and in the Muslim World. He emphasized that, the Brotherhood caused much troubles to Saudi Arabia during the 1991 Gulf war. In his statement, the Saudi minister namely mentioned some of the Brotherhood's international leaders such as the Sudanese politician Hassan al-Turabi, the Tunisian, Rashid al-Ghanushi, the Turkish, Najm al-Din Arbakan and so forth ${ }^{25}$. Furthermore, Dubai's police leader, DhahiKhalfan accused in 2012, based on his own investigation that, the regional Muslim Brotherhood was planning to take over the Gulf region's leadership started from Kuwait in $2013^{26}$. The regional authorities' confrontation against the Brotherhood covered almost all countries in the Arab World; however, some countries offer the organization the right to politically participate in the respective country such as Jordan, Morocco and Kuwait, while others do not politically tolerate the organization to officially engage any kind of activities such as Saudi Arabia, Unites Arab Emirates and currently Egypt.

Another aspect connected to the long term agenda is the International Tanzeem's networks (International Organizations). The International Networks go back to the Islamic religion principal calling for "One Ummah". "One Ummah" refers to the unitary vision of the Islamic religion. This ambition was behind the formation of one of the 10 Empires $^{27}$ : Othman Empire that endured for 6 centuries. The Brotherhood's global network was not much visible until the clash between Nasser's regime and the Organization that caused the dissolution of the letter in 1954, and made many active members fled to Europe and to the gulf countries in particular. "During the 1950s and 1960s, thousands of Muslim students left the Middle East to study at German universities, drawn not only by the German institutions' technical reputations but also by a desire to escape repressive regimes. Egyptian ruler Gamal Abdel Nasser's regime was especially vigorous in its attempts to root out the Islamist opposition. Beginning in 1954, several members of the Muslim Brotherhood fled Egypt to escape arrest or assassination. West Germany provided a welcome refuge" ${ }^{, 28}$.

EMB's members' presence in Europe was noticeable due to Muslim

\footnotetext{
${ }^{25}$ Fuller Graham, (Aljazeera.net 2004)

خلفـان/26 Aljazeera.net, (2012). Available at http://www.aljazeera.net/news/arabic/201memb2/3/25

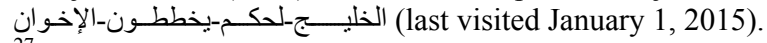

${ }^{27}$ The 10 Great Empires in the Human History are Akkadian Empire (2300 BC-2200 BC), Achaemenid Empire (550 BC-330 BC), Roman Empire (27 BC-AD 476/1453), Umayyad Caliphate (661-750), Qing Dynasty (1890-1912), Russian Empire (1721-1917), Mongol Empire (1206-1368), Mughal Empire (1526-1858), British Empire (16th and early 17th centuries), Ottoman Empire (12991923), Greatest Empire (2012).

${ }^{28}$ Vidino Lorenzo, The Muslim Brotherhood's Conquest of Europe, 12(1) MidDLE EAST QUARTERLY 25-34 (Washington, DC: 1994-2015, the Middle East Forum 2005).
} 
activities and establishing Mosques and Islamic centres. Desiring to survive in foreign countries, certain members became active as the new countries started to sound as their permanent places to live. "One of the Muslim Brotherhood's first pioneers in Germany was Sa'id Ramadan, the personal secretary of Muslim Brotherhood founder, Hassan al-Banna. Ramadan, an Egyptian who had led the Muslim Brotherhood in Palestine in 1948, moved to Geneva in 1958 and attended law school in Cologne. In Germany, he founded what has become one of Germany's three main Muslim organizations, the Islamische Gemeinschaft Deutschland (Islamic Society of Germany, IGD), over which he presided from 1958 to $1968^{\prime 29}$.

To sum up, the international Brotherhood's diplomat, Youssef Nada, one of the Muslim Brotherhood's financial masterminds as well, "who run Al-Taqwa bank, and a web of companies headquartered in locations such as Switzerland, Liechtenstein and the Bahamas stated between 1973 to 2002"30 stated, "It is true that the Moslem Brotherhood is part of those who are calling for globalization and world order. The main difference is that our call is not based on race, language, color, or privilege to those who are powerful similar to the Greeks or the Romans, but based on justice, tolerance, peace, equality in harmony irrespective of race, colour, religious or culture, understanding, accepting and assisting the others, feeling the impulse of the others' hearts, spreading happiness and kindness, solidarity towards those who suffer, promotion of brotherly environment, to prevent arrogance and evil ambitions to reign supreme" ${ }^{, 31}$.

However, as it has been stated earlier, the accusation against the organization of hiding an extremism ideology is the mainstream among the Middle East authorities, secular parties, many western scholars and so forth. Accordingly, in 2014, "the British Prime Minister David Cameron has ordered an investigation into the Muslim Brotherhood over concerns the group is planning radical activities from a base in London. The intelligence agencies MI5 and MI6 have been tasked to gather information on the "philosophy and activities" of the group after several leaders fled to London following the toppling of Egyptian president Mohammed Morsi last year according to the report" ${ }^{32}$. This is to argue that, the organization faces pressure outside as well as inside Egypt due to its expansionism ideology and agenda.

\footnotetext{
${ }^{29} \mathrm{Id}$.

${ }^{30} \mathrm{Id}$.

${ }^{31}$ Nada Yussef, Case Study of Misusing (Fighting Terrorism Slogans), to Encircle Muslim Activists, WATCH VIDEO INTERVIEWS (2006).

${ }^{32}$ ArutzSheva, IsRael National News.com (2014) Available at

http://www.israelnationalnews.com/News/News.aspx/179165 (last visited February 8, 2015).
} 


\section{CONCLUSION}

As an aid to the readers, this section summarizes and discusses the general findings of the study. First, the paper showed that, the author used secondary sources composed of scholarly materials from Western scholars and the Egyptian Muslim Brotherhood's ideologists, writers and activists. The aim of the study was the Egyptian Muslim Brotherhood's (EMB) history focusing on its ideology and agenda. The findings of the study explained the political, social and economic environments from which the ideology and the agenda of EMB come from. In this regard, the 18th century economic development in the Western Europe influenced the Arab and the Muslim Worlds in a way that Muslim scholars attempted to present an alternative to the attractiveness of the Western modernization. However, the EMB founded in 1928, despite its tirelessly struggle, full of confrontations and flexibility at the same time towards the domestic as well as the international community actors failed to achieve its first step agenda which is ruling Egypt. EMB's regional and international expansionism ambition might be the response to answer to the research question: what's wrong with EMB? 